\author{
JURNAL PENJAMINAN MUTU \\ LEMBAGA PENJAMINAN MUTU \\ INSTITUT HINDU DHARMA NEGERI \\ DENPASAR
}

Volume 3 Nomor 2 Agustus 2017

ISSN : 2407-912X (Cetak)

ISSN : 2548-3110 (Online)

http://ejournal.indn.ac.id/index.php/JPM

\title{
MEMAHAMI PERAN MASYARAKAT DAN PEMERINTAH DALAM KEMAJUAN MUTU PENDIDIKAN DI INDONESIA
}

\author{
Oleh \\ I Nyoman Temon Astawa \\ Institut Hindu Dharma Negeri Denpasar \\ temonastawa@gmail.com
}

Diterima 30 Januari 2017, direvisi 07 Agustus 2017, diterbitkan 31 Agustus 2017

\begin{abstract}
The development of the quality of education in Indonesia should be done together not only for the government and educators but to the community, because the community has an important role to achieve a goal of educationquality. In fact in the field of our education system fully devolved public education students or learners to teachers. This can be caused by a lack of public understanding of the importance of the role of the community in education.
\end{abstract}

Keywords: Role of Civil Society and Government, Education Quality Progress.

\section{PENDAHULUAN}

Pembangunan kualitas pendidikan di Indonesia harus dilakukan secara bersamasama tidak hanya bagi kaum pemerintah dan para pendidik tetapi juga perlu melibatkan masyarakat, karena masyarakat memiliki peran penting untuk tercapainya suatu tujuan pendidikan yang berkualitas.Namun kenyataannya masyarakat menyerahkan sepenuhnya pendidikan siswa atau peserta didik hanya kepada para guru.Hal tersebut disebabkan oleh karena kurangnya pemahaman masyarakat terhadap pentingnya peran masyarakat dalam dunia pendidikan.

Masalahpendidikan sebagai proses pemanusiaan manusia membutuhkan sinergi antar komponen dan membutuhkan kesepa- haman visi seluruh stake holder yang terlibat. Komponen pendidikan yang meliputi raw material (input siswa), tools (alat-alat dan sarana prasarana), serta process (metode pembelajaran) adalah sebuah sistem yang akan menentukan kualitas out put (lulusan), sedangkan stake holder yang terdiri atas siswa, guru, kepala sekolah, wali murid, dinas terkait dan pemerintah daerah harus se-visi dan sinergi sehingga memperlancar dan mempermudah pencapaian tujuan baik tujuan akademis maupun pembentukan moral.

Kualitas pendidikan di Indonesia saat ini dinilai banyak pihak belum berkualitas, sebagai indikatornya adalah kualitas Human Development Index (Indeks Kualitas Manusia) berada di bawah negara-negara Asia Tenggara 
lainnya seperti Singgapura, Thailand, bahkan Vietnam. Ada beberapa faktor penyebab rendahnya kualitas pendidikan di tanah air antara lain: proses pembelajaran belum memperoleh perhatian optimal, masih ada para pendidik tidak memahami fungsi dan tujuan dari pendidikan. Guru lebih banyak bekerja sendirian, forum MGMP (Musyawarah Guru Mata Pelajaran) belum berfungsi optimal. Dengan tidak diketahuinya fungsi dan tujuan dari pendidikan tersebut oleh pendidik maka suatu pendidikan akan tidak terarah atau tidak mencapai suatu tujuan pendidikan.

\section{PEMBAHASAN}

\subsection{Fungsi dan Tujuan Pendidikan}

\subsubsection{Fungsi Pendidikan}

1. Fungsi Pendidikan: serangkaian tugas atau misi yang diemban dan harus dilaksanakan oleh pendidikan

2. Fungsi pendidikan keluarga, mengembangkan keyakinan beragama, nilainilai kebudayaan, nilai moral dan ketrampilan

3. Fungsi pendidikan sekolah, memberikan berbagai pengetahuan dan ketrampilan serta mengembangkan berbagai nilai dan sikap.

4. Fungsi pendidikan luar sekolah, mengembangkan pengetahuan dan kemampuan warga masyarakat untuk berperan dalam berbagai bidang kehidupan secara produktif, efisien dan efektif

Menurut Havelock \& Huberman (1997: 25), sistem pendidikan suatu negara memiliki beberapa fungsi sebagai berikut :

1. Untuk menciptakan pemahaman identitas nasional melalui pengajaran sejarah dan peristiwa-peristiwa yang terjadi.
2. Untuk memberikan bahasa percakapan dan tulis secara umum yang mungkin tidak ada orang yang mengadakan sebelumnya.

3. Untuk menanamkan seperangkat nilainilai sosial politik.

4. Untuk memberikan seperangkat keterampilan spesifik yang akan memungkinkan ekonomi yang seimbang dan terpadu menjadi kenyataan.

Fungsi dan tujuan pendidikan dalam UU RI Nomor 20 Tahun 2003,Bab II Pasal3disebutkan sebagai berikut,"Pendidikan nasional berfungsimengembangkan kemampuan dan membentk watak serta peradaban bangsa yang bermartabat dalam rangka mencerdasakan kehidupan bangsa,bertujuan untuk mengembangkan potensi peserta didik agar menjadi manusia yang beriman dan bertakwa kepada Tuhan Yang Maha Esa, berakhlak mulia, sehat, berilmu, cakap, kreatif, mandiri, dan menjadi warga negara yang demokratis serta bertangggung jawab".

\subsubsection{Tujuan Pendidikan}

Pendidikan diupayakan dengan berawal dari manusia apa adanya (aktualisasi) dengan mempertimbangkan berbagai kemungkinan yang apa adanya (potensialitas), dan diarahkan menuju terwujudnya manusia yang seharusnya atau manusia yang dicita-citakan (idealitas). Tujuan pendidikan itu tiada lain adalah manusia yang beriman dan bertaqwa kapada Tuhan, berakhlak mulia, sehat, cerdas, berperasaan, berkemauan, dan mampu berkarya; mampu memenuhi berbagai kebutuhan secara wajar, mampu mngendalikan hawa nafsunya; berkepribadian, bermasyarakat dan berbudaya. Implikasinya, pendidikan harus berfungsi untuk mewujudkan (mengembangkan) berbagai potensi yang ada pada manusia dalam konteks dimensi keberagaman, moralitas, moralitas, individualitas/personalitas, sosialitas dan keberbudayaan secara menyeluruh dan 
terintegrasi. Dengan kata lain, pendidikan berfungsi untuk memanusiakan manusia.

Tujuan pendidikan menurut UNESCO pada 2015 ada enam tujuan pendidikan yang disepakati secara internasional untuk memenuhi kebutuhan belajar semua anak,remaja dan dewasa.

1 Memperluas dan meningkatkan keperawatan dan pendidikan anak usia dini yang komperhensif,terutama bagi anak-anak yang paling rentan dam kurang beruntung.

2 Memastikan bahwa tahun 2015,semua anak khususnya anak perempuan,anak-anak dalam keadaan sulit dan mereka yang termasuk etnik minoritas,memiliki akses ke pendidikan dasar lengkap,gratis dan wajib dengan kualitas yang baik.

3 Memastikan kebutuhan belajar semua anak muda dan orang dewasa terpenuhi melalui akses yang adil terhadap pembelajaran yang tepat dan program ketrampilan hidup.

4 Mencapai 50 persen perbaikan dalam tingkat keaksaran dewasa menjelang tahun 2015 terutama bagi perempuan,dan akses yang adil pada pendidikan dasar dan berkelanjutan bagi semua orang dewasa.

5 Menghapus disparitas gender dalam pendidikan dasar dan menengah pada 2005 dan mencapai kesetaraan gender dalam pendidikan pada 2015 dengan fokus jaminan bagi perempuan atas akses penuh dan sama pada prestasi dalam pendidikan dasar dengan kualitas yang baik

6 Meningkatkan semua akses pendidikan dan memastikan keunggulan semua sehingga hasil pembelajaran yang diakui dan terukur dicapai oleh semua,terutama aksaran,berhitung,dan ketrampilan hidup yang penting.
Tujuan pendidikan menurut Havelock \& Huberman (1977: 35),dalam suatu sistem yang paling besar adalah sistem pendidikan,termasuk unsur-unsur pendidikan formal dan non formal; yang bertujuan lebih baik unuk pembangunan negara secara keseluruhan melalui penyediaan tenaga kerja yang terampil untuk perananperanan yang beragam dan melaluipengajaran pada generasi baru mengenai tujuan -tujuan masyarakat secara menyeluruh dan alat-alat pemenuhan mereka

Ivan Illich (Mudyaharjo,2002:49) berpendapat bahwa suatu sistem pendidikan yang baik harus mempunyai tiga tujuan.

1. Memberikan kesempatan kepada semua orang untuk bebas dan mudah memperoleh sumber belajar pada setiap saat.

2. Memungkinkan semua orang yang ingin memberikan pengetahuan mereka kepada orang lain dengan mudah melakukannya,demikian pula bagi yang ingin mendapatkannya.

3. Menjamin tersedianya masukanumum yang berkenaan dengan pendidikan.

Ivan Illich menekankan pada adanya kebebasan setiap orang untukmemperoleh akses pada sumber-sumber belajar yang memungkinkan mereka leluasa mengembangkan potensi dirinya guna mencapai tujuan hidup mereka.

Tujuan Pendidikan Nasional di Negara Indonesia adalah untuk meningkatkan kualitas manusia Indonesia,yaitu manusia yang beriman dan bertaqwa terhadap Tuhan Yang Maha Esa,berbudi pekerti luhur, berkepribadian, mandiri, tangguh, cerdas, kreatif, trampil, disiplin, beretos kerja, profesional, bertanggung jawab, dan produktif serta sehat jasmani dan ruhani.Pendidikan juga harus menumbuhkan jiwa patriotik dan mempertebal rasa cinta tanah air, meningkatkan semangat kebangsaan, dan kesetiakawanan sosial serta sadar pada sejarah bangsa dan sikap menghargai jasa para 
pahlawan serta berorientasi masa depan. Iklim belajar dan mengajar yang dapat menumbuhkan rasa percaya diri dan budaya belajar di kalangan masyarakat terus dikembangkan agar tumbuh sikap dan perilaku yang kreatif,inovatif, dan keinginan untuk maju (GBHN,1993: 95). Berdasarkan kutipan diatas,dapat disimpulkan bahwa tujuan pendidikan secara umum adalah mengembangkann segala potensi bawaan manusia secara integral,silmutan,dan berkelanjutan agar menusia mampu melaksanakan tugas dan kewajiban dalam kehidupan guna mencapai kebahagian dimasa sekarang dan masa mendatang.

\subsection{Peranan Masyarakat dalam Kemajuan Mutu Pendidikan}

Meningkatkan peran serta masyarakat memang sangat erat berkait dengan pengubahan cara pandang masyarakat terhadap pendidikan. Ini tentu saja bukan hal yang mudah untuk dilakukan.Akan tetapi, bila tidak sekarang dilakukan dan dimulai, kapan rasa memiliki, kepedulian, keterlibatan, dan peran serta aktif masyarakat dengan tingkatan maksimal dapat diperoleh dunia pendidikan.

Ada 7 tingkatan peran serta masyarakat (dirinci dari tingkat partisipasi terendah ke tinggi), yaitu:

1. Peran serta dengan menggunakan jasa pelayanan yang tersedia. Jenis ini adalah jenis yang paling umum Pada tingkatan ini masyarakat hanya memanfaatkan jasa sekolah untuk mendidik anak-anak mereka.

2. Peran serta dengan memberikan kontribusi dana, bahan, dan tenaga. Pada jenis ini masyarakat berpartisipasi dalam perawatan dan pembangunan fisik sekolah dengan menyumbangkan dana, barang, atau tenaga.

3. Peran serta secara pasif. Masyarakat dalam tingkatan ini menyetujui dan menerima apa yang diputuskan pihak sekolah (komite sekolah), misalnya komite sekolah memutuskan agar orang tua membayar iuran bagi anaknya yang bersekolah dan orang tua menerima keputusan itu dengan mematuhinya.

4. Peran serta melalui adanya konsultasi. Pada tingkatan ini, orang tua datang ke sekolah untuk berkonsultasi tentang masalah pembelajaran yang dialami anaknya.

5. Peran serta dalam pelayanan. Orang tua/masyakarat terlibat dalam kegiatan sekolah, misalnya orang tua ikut membantu sekolah ketika ada studi tur, pramuka, kegiatan keagamaan, dsb.

6. Peran serta sebagai pelaksana kegiatan. Misalnya sekolah meminta orang tua/masyarakat untuk memberikan penyuluhan pentingnya pendidikan, masalah jender, gizi, dsb. Dapat pula misalnya, berpartisipasi dalam mencatat anak usia sekolah di lingkungannya agar sekolah dapat menampungnya, menjadi nara sumber, guru bantu, dsb.

7. Peran serta dalam pengambilan keputusan. Orang tua/masyarakat terlibat dalam pembahasan masalah pendidikan baik akademis maupun non akademis, dan ikut dalam proses pengambilan keputusan dalam Rencana Pengembangan Sekolah.

Pada saat dimana suatu program pembangunan didominasi oleh peran pemerintah dan peran masyarakat lemah, maka masyarakat hanya ditempatkan sebagai saluran mempercepat program-program pembangunan itu. Sebaliknya, apabila kemudian peran masyarakat kuat dan ditempatkan sebagai subjek, maka akan bermakna sebagai upaya pemberdayaan atau penguatan masyarakat, baik secara institusional maupun perseorangan anggota masyarakat (Karsidi, 2002). 
Penguatan masyarakat secara institusional bisa diartikan sebagai pengelompokan anggota masyarakat sebagai warga negara mandiri yang dapat dengan bebas dan egaliter bertindak aktif dalam wacana dan praksis mengenai segala hal yang berkaitan dengan masalah kemasyarakatan pada umumnya. Termasuk di dalamnya adalah jejaring, pengelompokan sosial yang mencakup mulai dari rumah tangga, organisasi - organisasi sukarela (termasuk partai politik), sampai organisasi - organisasi yang mungkin pada awalnya dibentuk oleh negara, tetapi melayani kepentingan masyarakat yaitu sebagai perantara dari negara di satu pihak dengan individu dan masyarakat di pihak lain (Hikam, 1993).

Belajar dari pengalaman bahwa ketika peran pemerintah sangat dominan dan peranserta masyarakat hanya dipandang sebagai kewajiban, maka masyarakat justru akan terpinggirkan dari proses pembangunan itu sendiri. Penguatan partisipasi masyarakat haruslah menjadi bagian dari agenda pembangunan itu sendiri, lebih-lebih dalam era globalisasi.Peranserta masyarakat harus lebih dimaknai sebagai hak daripada sekadar kewajiban.Kontrol rakyat (anggota masyarakat) terhadap isi dan prioritas agenda pengambilan keputusan pembangunan harus dimaknai sebagai hak masyarakat untuk ikut mengontrol agenda dan urutan prioritas pembangunan untuk dirinya atau kelompoknya. Oleh karena itu, tidak akan dapat diterima jika satu golongan mendikte keinginan dan kepentingannya dalam isi dan prioritas agenda pengambilan keputusan pembangunan, apakah itu golongan di dalam negeri seperti pejabat pemerintah atau usahawan, dan eksternal seperti kekuatan besar misalnya lembaga (keuangan) internasional (Karsidi, 2002).

Tanggung jawab pengembangan pendidikan sebagai proses sosialisasi adalah berada pada orang tua dan kelompokkelompok masyarakat yang berkepentingan. Tanggung jawab tersebut tidak pernah lepas tetapi pernah mengendor, sejalan dengan dominannya paradigma pembangunan sentralistik.Oleh karena paradigma tersebut telah bergeser menuju kepada peluang yang lebar bagi teraktualisasikannya kembali partisipasi masyarakat, maka perlu segera dilakukan upaya pemulihan dan pengembalian tanggung jawab masyarakat terhadap pengembangan pendidikan baik dalam skala mikro maupun skala makro.Inilah yang saya sebut sebagai reaktualisasi partisipasi masyarakat, karena sebenarnya yang bertanggung jawab dalam hal ini adalah justru masyarakat itu sendiri. Mengacu pada lingkup partisipasi masyarakat, maka dalam pengembangan pendidikan, masyarakat harus dilibatkan sejak dari proses perencanaan, pelaksanaan, pemanfaatan hasil dan evaluasinya.

Program-program pembelajaran di sekolah berupa desain kurikulum dan pelaksanaannya, kegiatan-kegiatan nonkurikuler sampai pada pengadaan kebutuhan sumber daya untuk suatu sekolah agar dapat berjalan lancar, tampaknya harus sudah mulai diberikan ruang partisipasi bagi pihak-pihak yang berkepentingan. Demikian pula di lembaga-lembaga pendidikan lainnya nonsekolah, ruang partisipasi tersebut harus dibuka lebar agar tanggung jawab pengembangan pendidikan tidak tertumpu pada lembaga pendidikan itu sendiri, lebih-lebih pada pemerintah sebagai penyelenggara negara.

Cara untuk penyaluran partisipasi dapat diciptakan dengan berbagai variasi cara sesuai dengan kondisi masing-masing wilayah atau komunitas tempat masyarakat dan lembaga pendidikan itu berada. Kondisi ini menuntut kesigapan para pemegang kebijakan dan manajer pendidikan untuk mendistribusi peran dan kekuasaannya agar bisa menampung sumbangan partisipasi masyarakat.Sebaliknya, dari pihak masyarakat (termasuk orang tua dan kelompok-kelompok masyarakat) juga harus belajar untuk kemudian bisa memiliki kemauan dan kemampuan berpartisipasi dalam 
pengembangan pendidikan.Sebagai contoh adalah tanggung jawab untuk menghasilkan output yang baik sesuai dengan rumusan harapan bersama. Demikian juga kelompokkelompok masyarakat lain, termasuk orang tua siswa. Dengan cara demikian, maka mutu pendidikan suatu lembaga pendidikan menjadi tanggung jawab bersama antara lembaga pendidikan dan komponen-komponen lainnya di masyarakat tersebut.

UU Sisdiknas, 2003 bahwa pemerintah dan pemerintah daerah berhak mengarahkan, membimbing, membantu, dan mengawasi penyelenggaraan pendidikan, serta berkewajiban memberikan layanan dan kemudahan penyelenggaraan pendidikan yang bermutu bagi setiap warga negara tanpa diskriminasi. Pemerintah dan pemerintah daerah juga wajib menjamin tersedianya dana guna terselenggaranya pendidikan bagi setiap warga negara dari usia tujuh sampai usia lima belas tahun. Lebih dari itu, sebenarnya peluang bagi orang tua/warga dan kelompok masyarakat masih sangatlah luas.Untuk itu, maka dalam kondisi kualitas layanan dan output pendidikan sedang banyak dipertanyakan mutu dan relevansinya, maka pemerintah seharusnya memberikan peluang yang luas bagi partisipasi masyarakat.Lebih dari itu, pemerintah perlu menyusun mekanisme sehingga orang tua dan kelompok-kelompok masyarakat dapat berpartisipasi secara optimal dalam pengembangan pendidikan di Indonesia. Keluarga adalah institusi yang sangat berperan dalam rangka melakukan sosialisasi, bahkan internalisasi, nilai-nilai pendidikan.Meskipun jumlah institusi pendidikan formal dari tingkat dasar sampai ke jenjang yang paling tinggi semakin hari semakin banyak, namun peran keluarga dalam transformasi nilai edukatif ini tetap tidak tergantikan.keluarga merupakan tempat pertumbuhan anak yang pertama di mana dia mendapatkan pengaruh dari anggotaanggotanya pada masa yang amat penting dan paling kritis dalam pendidikan anak, yaitu tahun - tahun pertama dalam kehidupanya (usia prasekolah). Sebab pada masa tersebut apa yang ditanamkan dalam diri anak akan sangat membekas, sehingga tak mudah hilang atau berubah sudahnya. Dari sini, keluarga mempunyai peranan besar dalam pembangunan masyarakat.Karena keluarga merupakan batu pondasi bangunan masyarakat dan tempat pembinaan pertama untuk mencetak dan mempersiapkan personil - personilnya.Karena itulah, peran keluarga dalam hal ini begitu berarti. Bahkan bisa dikatakan bahwa tanpa keluarga, nilai-nilai pengetahuan yang didapatkan di bangku meja formal tidak akan ada artinya sama sekali. Sekilas memang tampak bahwa peran keluarga tidak begitu ada artinya, namun jika direnungkan lebih dalam, siapa saja akan bisa merasakan betapa berat peran yang disandang keluarga.

Problem yang dialami oleh 'anak jalanan' untuk memperoleh pendidikan salah satunya adalah minimnya, bahkan tak adanya peran keluarga.Kalaupun akhirnya mereka bersekolah, mereka hanya mendapatkan pengetahuan formal saja.Sementara kasih sayang, sopan santun, moralitas, cinta dan berbagai nilai afektif lainnya sulit mereka dapatkan.Mereka merasa tidak ada tempat yang baik untuk berlindung dan mengungkapkan seluruh perasaan secara utuh dan bebas.Umumnya mereka tidak memiliki keluarga yang mengemban peran tersebut.Kalaupun mereka memiliki keluarga, tidak ada situasi yang kondusif untuk saling berbagi perasaan antar anggota dalam sebuah keluarga.Ini merupakan salah satu kesulitan yang dihadapi oleh lembaga-lembaga swadaya masyarakat yang mencoba memberdayakan 'anak jalanan'. Mungkin persoalan sulitnya bagaimana dia mendapatkan pendidikan secara formal, tidak sesulit bagaimana dia memperoleh kasih sayang sejati.

Dari paparan itu dapat dimengerti betapa peran penting keluarga dalam rangka mengemban misi-misi pendidikan tidak bisa diabaikan.Di dalam keluarga tercermin jalinan kasih dan cinta dalam ikatan emosional, darah dan kekerabatan sangat mendominasi. Dengan demikian, keluarga merupakan cetak biru (blue print) akan menjadi apa seorang anak kelak. Sebagian orang secara tidak sadar mengatakan 
bahwa sebenarnya peran keluarga adalah sekunder, alias hanya menjadi pelengkap saja.Sebab pengetahuan formal sudah mereka dapatkan di bangku sekolahan.Logika ini tidak saja keliru secara etis, tapi juga patut dipertanyakan pula pandangan moralnya terhadap keluarga.Keluarga merupakan institusi pendidikan pertama dan utama, kemudian baru dilengkapi dengan nilai-nilai pengetahuan yang didapatkan dari bangku sekolahan.

\subsection{Peran Pemerintah Dalam Kemajuan Mutu Pendidikan}

Pemerintah sebagai penyelenggara negara dalam bidang pendidikan, seperti yang diamanatkan oleh UU Sisdiknas, 2003 bahwa pemerintah dan pemerintah daerah berhak mengarahkan, membimbing, membantu, dan mengawasi penyelenggaraan pendidikan, serta berkewajiban memberikan layanan dan kemudahan penyelenggaraan pendidikan yang bermutu bagi setiap warga negara tanpa diskriminasi. Pemerintah dan pemerintah daerah juga wajib menjamin tersedianya dana guna terselenggaranya pendidikan bagi setiap warga negara dari usia tujuh sampai usia lima belas tahun. Lebih dari itu, sebenarnya peluang bagi orang tua/warga dan kelompok masyarakat masih sangatlah luas.

Pendidikan merupakan sumber ilmu dan pengetahuan yang wajib diperoleh oleh setiap manusia.Baik itu pendidikan di sekolah maupun pendidikan di luar sekolah. Meningkatkan kesadaran dalam menimba ilmu didalam dunia pendidikan sudah dicanangkan pihak pemerintah dari Sekolah Dasar sampai ke Perguruan Tinggi. Tujuan pemerintah meningkatkan mutu pendidikan setiap warga negaranya yaitu untuk meningkatkan sumber daya manusia di Indonesia.Peningkatan SDM diperlukan agar setiap warga Negara Indonesia mempunyai pendidikan yang layak dan bisa mengembangkan kemampuan yang diperoleh didalam pendidikan bisa disalurkan untuk Pemerintah dan dapat bersaing dengan pekerjapekerja dari dalam maupun luar negeri.

Di dalam negeri sendiri sumber daya alamnya melimpah, tapi melimpahnya SDA tidak dibarengi dengan melimpahnya SDM Indonesia itu sendiri.Sehingga, SDA yang melimpah tadi dikelola oleh pihak asing dan Indonesia hanya memperoleh beberapa persen dari keuntungan pengolahan SDA tadi.Hal itu merupakan tamparan bagi masyarakat Indonesia khususnya buat permerintah.

Untuk itu peningkatan SDM perlu ditingkatkan sampai ke level yang semestinya. Tapi, dalam peningkatan SDM yang ada.Pemerintah harus berperan aktif didalam peningkatannya yaitu di aspek Pendidikan. Karena, pendidikan yang layak dan baik itu akan menunjang SDM Indonesia. Untuk itu, ada beberapa bentuk peran pemerintah didalam peningkatan pendidikan yaitu peran sebagai pelayan masyarakat, sebagai fasilitator, sebagai pendamping, sebagai mitra dan berperan sebagai penyandang dana. untuk lebih jelasnya peran - peran pemerintah didalam pendidikan yaitu:

1) Peran sebagai pelayan masyarakat. Pemerintah berperan sebagai pelayan masyarakat didalam pendidikan yaitu pemerintah melayani kebutuhan masyarakat mengenai tentang pendidikan. Pemerintah mengutamakan masyarakat untuk dilayani agar pengembangan pendidikan setiap masyarakat bisa menjadi lebih baik lagi.

2) Peran sebagai fasilitator. Pemerintah berperan sebagai fasilitator yaitu pemerintah sebagai penyedia tempat atau penyedia fasilitas untuk pendidikan. Mempunyai peran seperti ini pemerintah seharusnyabisa berbaur dalam masyarakat mendengarkan aspirasi masyarakat mengenai fasilitas sekolah yang ada di daerah tersebut dan benar-benar mengecek kebenaran pengaduan masyarakat akan kurangnya atau perlunya perbaikan fasilitas.

3) Peran sebagai pendamping. Pemerintah selain mempunyai tugas utama menjadi pelayan masyarakat, tapi pemerintah mempunyai tugas 
sebagai pendamping di dalam pendidikan. Bisa mendampingi masyarakat, menerima keluhan masyarakat mengenai pendidikan sehingga masyarakat bisa merasa terus ada pihak pemerintah yang akan selalu ada untuk mendampingi buat mereka untuk memperoleh jawaban atas keluhan yang mereka rasakan mengenai pendidikan yang ada di daerahnya masing-masing. Masyarakat akhirnya merasakan peran pemerintah begitu nyata karena selalu ada di sekitar masyarakat itu sendiri.

4) Peran sebagai mitra. Pemerintah berperan sebagai mitra disini yaitu pemerintah menjadi rekan kerjasama antara pihak sekolah dan masyarakat.Pemerintah dalam menentukan kebijakan dalam pendidikan harus bisa mengerti dan memahami keadaan pendidikan setiap daerah.Sehingga nantinya tidak ada unsur pemaksaan yang dilakukan oleh pihak pemerintah. Untuk itu, setiap keputusan bisa dibicarakan dengan pihak sekolah dan masyarakat mengenai kebijakan yang akan dibuat mengenai pendidikan. Hal ini dilakukan agar tidak terjadi kesalah pahaman dalam menentukan tentang kebijakan baru.

5) Peran sebagai penyandang dana.Pemerintah sebagai penyandang dana yaitu pemerintah memmberikan bantuan dana kepada instansi sekolah yang memerlukan dan memberikan dana kepada siswa yang membutuhkan.

\subsection{Bentuk Hubungan Lembaga Pendidikan Dengan Masyarakat.}

Lembaga pendikan atau juga bisa disebut sekolah yaitu tempat sarana untuk menimbailmu pendidikan.Sekolah bisa didirikan didaerah tersebut karena ada masyarakat yang ada di daerah itu.Sehingga Sekolah tidak bisa berdiri sendiri tanpa adanya konstribusi dari masyarakat.Untuk menghidupkan sekolah tersebut harus ada peran masyarakat di dalamnya.Baik peran yang nyata maupun peran yang tidak dilihat orang banyak.Untuk itu, Lembaga pendidikan mempunyai bentuk hubungan dengan masyarakat agar tidak ada kesenjangan antara lembaga sekolah dengan masyarakat.Ada beberapa bentuk hubungan lembaga pendidikan dengan masyarakat. Secara jelas diantaranya yaitu:

1) Mengikutkan warga sekolah dalam kegiatan pemasyarakatan. Warga sekolah disini yaitu bisa siswa. Didalam kegiatan pemasyarakatan siswa bisa diikutkan secara langsung dengan kegiatan bersama masyarakat agar siswa dari awal mengerti dan memahami betul interaksi social di luar sekolah itu seperti apa wujudnya. Sehingga nantinya siswa tidak merasa canggung bila berhadapan dengan masyarakat yang luas.

2) Penyediaan fasilitas sekolah untuk keperluan masyarakat.Sekolah bisa memberikan bantuan berupa fasilitas kepada masyarakat untuk keperluan yang dibutuhkan oleh masyarakat tersebut.Sehingga masyarakat tidak bersusah payah dalam penyewaan tempat karena di sekolah yang ada dimasyarakat tersebut sudah mau memberikan fasilitas tempat untuk menunjang keperluan masyarakat tersebut.

3) Mendayagunakan tokoh - tokoh potensial dalam masyarakat guna menunjang pendidikan.Misalnya dalam bentuk penanaman materi materi yang penting bagi siswa dan guru merasa kemampuannya dibidang materi itu belum menguasai betul.Sehingga memerlukan tokohtokoh dalam masyarakat tersebut untukmembantu memberikan materi.

4) Mengikutsertakan sekolah dalam menunjang pelaksanaan pendidikan, yaitu mengikutkan warga sekolah dalam pelaksanaan pendidikan yang ada di dalam lingkup sekolah maupun 
diluar sekolah. Sehingga warga sekolah menjadi aktif dibidang pendidikan antara pendidikan di dalam sekolah maupun diluar sekolah.

5) Menjalin hubungan dengan instansi lain.Sekolah atau lembaga pendidikan perlu menjalin hubungan dengan pihak instansi lain. Hal ini bertujuan agar meningkatkan pengetahuan,informasi atau aspek yang lainnya tentang instansi terkait.Instansi -instansi ini berperan penting dalam sekolah tersebut terutama warga sekolahnya. Jadi instansi ini bisa dijadikan partner yang baik dan kegiatannya diperlukan untuk sekolah.

\section{SIMPULAN}

1. Pendidikan nasional berfungsi mengembangkan kemampuan dan membentk watak serta peradaban bangsa yang bermartabat dalam rangka mencerdasakan kehidupan bangsabertujuan untuk mengembangkan potensi peserta didik agar menjadi manusia yang beriman dan bertakwa kepada Tuhan Yang Maha Esa, berakhlak mulia, sehat, berilmu, cakap, kreatif, mandiri, dan menjadi warga negara yang demokratis serta bertangggung jawab.

2. Masyarakat selaku pengguna jasa lembaga pendidikan memiliki peran penting dalam pendidikan yang meliputi peran serta perseorangan, kelompok, keluarga, organisasi profesi, pengusaha dan organisasi kemasyarakatan dalam penyelenggaraan dan pengendalian mutu pelayanan pendidikan selain itu masyarakat dapat berperan serta sebagai sumber, pelaksana dan pengguna hasil.

3. Pemerintah dan pemerintah daerah berhak mengarahkan, membimbing, membantu, dan mengawasi penyelenggaraan pendidikan, serta berkewajiban memberikan layanan dan kemudahan penyelenggaraan pendidikan yang bermutu bagi setiap warga negara tanpa diskriminasi.

\section{DAFTAR PUSTAKA}

Ahmadi,Abu dan Nur Uhbiyati. 2007. Ilmu Pendidikan. Jakarta : Rineka Cipta.

Arif,Saiful. 2007. Pendidikan karakter. Yogyakarta : balai pustaka

Chan,Sam M. dan Tuti. 2005. Kebijakan Pendidikan Era Otonomi Daerah, Jakarta: Raja Grafindo Persada.

Dwiningrum,Siti Irene Astuti. 2011. Desentralisasi dan Partisipasi Masyarakat Dalam Pendidikan. Yogyakarta: Pustaka Pelajar

Sugiyono. 2007. Penelitian Pendidikan. Jakarta : PT Rajawali Press

Syarbaini. 2012Pendidikan Pancasila Di Perguruan Tinggi (Implementasi NilaiNilai Karakter Bangsa). Ghalia Indonesia

http://chaqoqo.staff.iainsalatiga.ac.id/2013/10/ 17/peran-pemerintah-dalam-pendidikan/

http://lailiakhiliyyah.blogspot.co.id/2011/11/ peran-pemerintah-dalammeningkatkan.html 